\title{
POPULATION CONTROL IN INDIA: PROGRESS AND PROSPECTS
}

\author{
S. N. Agarwala*
}

I

\section{Population Trends in India}

Among the countries, India ranks second in population and seventh in land area. It has fifteen per cent of the population and 2.2 per cent of the area of the world. Its population in 195 I was $357,000,000-$-about ninety per cent of that of Europe excluding the Soviet Union, and sixty per cent of that of China. The density of its population, $3^{12}$ persons per square mile, is forty per cent higher than that of Europe excluding the Soviet Union, and 250 per cent higher than that of China. Its land area, however, is only two-thirds that of Europe excluding the Soviet Union.

At the time of the $189 \mathrm{I}$ census, India's population was $236,000,000$. Thirty years later-that is, in I92I-its population had increased by $12,000,000$. During the next thirty years, from I92I to I95I, however, India's population increased by I09,000,000nine times as much. ${ }^{1}$ It is clear from table one that before 1921 , one decade of rapid population growth was followed by another decade of slow growth, and, at times, even by negative growth. This was primarily owing to frequent epidemics and famines. For example, it is estimated that India lost more than $60,000,000$ people at the time of the influenza epidemic of I9I8; and during the period I898-I9r8, approximately half a million deaths were annually caused by plague. But since I92I, India has been relatively free from the ravages of epidemics and famines, and as is indicated in table two, the consequent decline in the death rate, rather than any increase in the birth rate, has resulted in a faster rate of population growth than before.

It is generally accepted that the current rate of population growth in India is nearly two per cent per annum. ${ }^{2}$ This high rate of population growth is unprecedented in India's history. It is not extraordinary, however, since the population growth rate currently prevailing in most of the Southeast Asian countries is also about the same. There are even some countries-e.g., Ceylon, Hongkong, Taiwan,

* B.A. 1944, Allahabad University; M.A. 1956, Ph.D. 1957, Princeton University. Head, Demographic Research Centre, Delhi University. Author, Beliefs and Practices Relating to Family Planning: A Study of Three Delhi Villages (r959); Fertility Control Through Contraception: A Study of Family Planning Clinics of Metropolitan Delhi (i959); Some Projections of India's Population (1959); Future Growth of India's Population (1959); Meas Age at Marriage in India (i957). Contributor to demographic periodicals.

${ }^{1}$ Census of InDiA, I95I, pt. I-A, at 122.

3 Indian Statistical Institute, National Sample Survey, Preliminary Estimate of Birth and Death Rates and of the Rate of Growth of Population (Fourteenth Round) 2 (i959); S. N. Agarwala, Some Projections of India's Population 6 (I959). 
TABLE I

\begin{tabular}{|c|c|c|c|}
\hline \multicolumn{4}{|c|}{ POPULATION OF INDIA } \\
\hline Years & $\begin{array}{c}\text { Population of the Pre- } \\
\text { sent Territory of India } \\
\text { (millions) }\end{array}$ & $\begin{array}{l}\text { Increase or } \\
\text { Decrease } \\
\text { (millions) }\end{array}$ & $\begin{array}{l}\text { Variation During the } \\
\text { Preceding Decade } \\
\text { (percentage) }\end{array}$ \\
\hline $\begin{array}{l}1891 \ldots \ldots \ldots \ldots \ldots \\
1901 \ldots \ldots \ldots \ldots \ldots \\
1911 \ldots \ldots \ldots \ldots \ldots \\
1921 \ldots \ldots \ldots \ldots \ldots \\
1931 \ldots \ldots \ldots \ldots \ldots \\
1941 \ldots \ldots \ldots \ldots \ldots \\
1951 \ldots \ldots \ldots \ldots \ldots\end{array}$ & $\begin{array}{l}235.9 \\
235.5 \\
249.0 \\
248.1 \\
275.5 \\
312.8 \\
356.9\end{array}$ & $\begin{array}{r}\because 0.4 \\
-0.4 \\
-0.9 \\
27.4 \\
37.3 \\
44.1\end{array}$ & $\begin{array}{r}\because 0.17 \\
-0.73 \\
-0.36 \\
11.04 \\
13.54 \\
14.10\end{array}$ \\
\hline
\end{tabular}

SOURCE: Censtes of InDIS, 1951, pt. I-A, at 122.

TABLE II

Birth and Death Rates of India (per thousand)

\begin{tabular}{|c|c|c|c|c|}
\hline \multirow{2}{*}{ Years } & \multicolumn{2}{|c|}{ Registered $^{\mathrm{a}}$} & \multicolumn{2}{|c|}{ Estimated } \\
\hline & Birth Rate & Death Rate & Birth Rate & Death Rate \\
\hline $\begin{array}{l}1911-20 \ldots \ldots \ldots \ldots \\
1921-30 \ldots \ldots \ldots \ldots \ldots \\
1931-40 \ldots \ldots \ldots \ldots \ldots \\
1941-50 \ldots \ldots \ldots \ldots \\
1951-55 \ldots \ldots \ldots \ldots\end{array}$ & $\begin{array}{l}36.94 \\
34.55 \\
34.17 \\
27.32 \\
26.10\end{array}$ & $\begin{array}{l}34.14 \\
26.29 \\
22.99 \\
20.10 \\
13.44\end{array}$ & $\begin{array}{l}48.1 \\
46.4 \\
45.2 \\
43.0^{c} \\
\ldots\end{array}$ & $\begin{array}{l}47.2 \\
36.3 \\
31.2 \\
30.0^{\circ} \\
\cdots\end{array}$ \\
\hline
\end{tabular}

Notz: : Central Statisticar Oraanisation, MinistRy of Hoys Aframs, Statjstical Ab8tact or Inp1a (1951-55).

b KingsLeY Davis, Popolation of India and Paxistan 85 (1951). It may be pointed out that Mir. S. P. Jain, the Crusis Actuary of 1951, has estimated that the birth and death rates in the 1941-51 decade were 30.9 and 27.4, respectively. Seo $\mathrm{S}$. P. JAIN, Estimation of BIrTh AND Deatr Rates IN Inpia duning 1941-51 Census (Censug of Indi3, 1951, Paper No. 6, 1054).

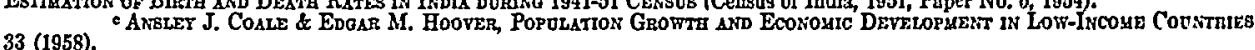

and Singapore-that have a growth rate of three per cent per annum.3 Currently, the United States' population is growing at a rate of 1.7 per cent, Argentina's at a rate of 2.2 per cent, Brazil's at a rate of 2.4 per cent, Mexico's at a rate of 2.8 per cent, and Costa Rica's at a rate of 3.6 per cent per annum. But what makes the population growth rate of India so menacing is that the base of its population is so large that the net annual addition to its population is about 8,000,000. Secondly, considering the backlog of underfed and ill-nourished population of India and the net annual increase, it may not be possible, despite efforts at economic planning, to maintain the population at a rising level of living. The third fact is that the death rate is declining, and there are reasonable chances that it will continue to decline owing to continuing improvements in the sanitary and health conditions of the masses. This implies that if the birth rate does not fall, the gap between birth and death rates will continuc to widen and India will be faced with the danger of a rapidly increasing multitude, or

${ }^{3}$ Statistics, 24 Population Index 9I (1958); U.N. Dep't of Economic and Social Affairs, Demo. graphic Yearbook tables I, 4 (U.N. Pub. Sales No. 1955.XIII.6); tables 1, 3 (U.N. Pub. Sales No. 1956.XIII.5).

'Statistics, 24 Population Index 91 (1958). 
what is often called the "population explosion." The general opinion, reflected in table three, is that India is likely to have a population of $423,000,000$ in $196 \mathrm{r}$, $472,000,000$ in 1966 , and about $523,000,000$ in $197 x$.

\section{TABLE III}

Some Recent Population Projections for India

(MILlions)

\begin{tabular}{|c|c|c|c|c|c|c|c|c|}
\hline \multirow{3}{*}{ Year } & \multirow{3}{*}{\multicolumn{2}{|c|}{ Agarwalab }} & \multirow{3}{*}{$\begin{array}{l}\text { Expert Committee } \\
\text { on Vital and Health } \\
\text { Statistics and also } \\
\text { Planning Commission }\end{array}$} & \multirow{3}{*}{$\begin{array}{l}\text { United } \\
\text { Nations }^{d}\end{array}$} & \multirow{2}{*}{\multicolumn{3}{|c|}{$\frac{\text { Coale \& Hoover }}{\text { (200 infant mortality) }}$}} & \multirow{3}{*}{$\begin{array}{l}\text { Ministry of } \\
\text { Labor and } \\
\text { Employment }\end{array}$} \\
\hline & & & & & & & & \\
\hline & & & & & High & Medium & Low & \\
\hline $\begin{array}{l}1951 \ldots \ldots \ldots \ldots \\
1956 \ldots \ldots \ldots \\
1961 \ldots \ldots \ldots \\
1966 \ldots \ldots \ldots \\
1971 \ldots \ldots \ldots \\
1976 \ldots \ldots \ldots \\
1981 \ldots \ldots \ldots\end{array}$ & $\begin{array}{l}357 \\
386 \\
423 \\
472 \\
526 \\
574 \\
626\end{array}$ & 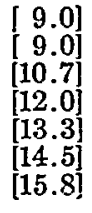 & $\begin{array}{l}357 \\
386 \\
425 \\
473 \\
\ldots \\
\cdots \\
\cdots\end{array}$ & $\begin{array}{l}357 \\
386 \\
417 \\
456 \\
504 \\
606\end{array}$ & $\begin{array}{l}357 \\
384 \\
422 \\
469 \\
524 \\
588 \\
662\end{array}$ & $\begin{array}{l}357 \\
384 \\
422 \\
469 \\
\mathbf{5 1 7} \\
\mathbf{5 5 7} \\
588\end{array}$ & $\begin{array}{l}357 \\
384 \\
418 \\
455 \\
490 \\
522 \\
549\end{array}$ & $\begin{array}{l}357 \\
384 \\
417 \\
457 \\
\cdots \\
\cdots \\
\cdots\end{array}$ \\
\hline
\end{tabular}

NoTzs: a In these projections, India's population has been taken as $356,900,000$ (or $357,000,000$ ) in 1951. It may, however, be noted that this does not include the population of Jammu and Kashmir and some tribal areas in Assam, which was estimated to be $5,000,000$ in that this does not include the population of Jammu and Kashmir and some tribal areas in Assam, which was estimated to be 5,000,000 in

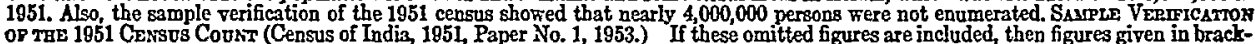
OP THE 1051 CENSUS CousT (Census of Indis, 185I, Paper No. 1, 1953.) If these omitted figures are included,
ets should also be taken into account to determine the projected population of India in the selected years. ets should also be taken into account to determine the projected population of Ind at 12 (1959). - Central Statisticat ORGanisation, Minisiat of HoMe afFams,

dU. N. Dep'T of Econoutc and Soctal Affatr, The Future Growth of Worlu PopdLation 74 (ST/SOA/Ser.A/28) (U. N. Pub. SalesNo. 1958. XIII. 2).

o Amber J. Conde \& Edgar M. Hoofer, Population Growth and Econonic Develophent in Low-Incoue Counthibs 59).

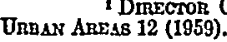

If we look to the demographic evolution historically, we find that when the western countries were economically backward and agriculture was their main occupation, their birth and death rates were both high and, therefore, their population multiplied slowly. ${ }^{5}$ With improvements in drinking-water facilities, improved sanitation, better transportation, etc., however, the death rate declined. But the birth rate stayed high. As a result, the population began to grow faster. In Europe, this period of rapid population expansion, called the "transition period," lasted three centuries and brought about a seven-fold increase in population. ${ }^{6}$ Whether the underdeveloped countries of the world will follow the same pattern of demographic evolution as was experienced by countries of the West cannot be said with any certainty. But it should now be possible to bring about a rapid decline in the death rate by the use of antibiotics, DDT spraying, BCG, etc. The examples of Ceylon; Formosa, Jamaica, Chile, Costa Rica, British Guiana, etc., may be cited in support

Thompson, Population, 34 AM. J. Soc. 959 (1929); Blacker, Stages in Population Growth, 39 Eugenics Rev. 88 (I947); Notestein, Economic Problems and Population Changes, in Eighrt International Conference of Agriculturat Economists, Proceedings, The Economics of Population and Food Supply I3 (1953); Notestein, Population-The Long View, in Theodore W. Schultz (Ed.), Food FOR THE WORLD 36 (I945).

'Notestein, Summary of the Demographic Background of Problems of Underdeveloped Countries, in Milbank Memoriat Fund, International Approaches to Problems of Underdeveloped Areas 2 (x948). 
of this. A fifty per cent decline in the death rate-say, from forty to twenty-which took more than too years to come about in the western countries, was brought about in these underdeveloped countries within a span of roughly ten years. The possibility of this remarkable achievement makes the problem of demographic transition in the underdeveloped countries all the more serious and puts a heavy responsibility on the shoulders of those who guide the destinies of these countries.

An important lesson that the underdeveloped countries have to learn from the experience of the western countries is that while a decline in the death rate can be brought about through imported modern medicines to control epidemics and through improvements in drinking-water facilities, methods of agriculture, and means of transportation, it is not possible to bring about a reduction of fertility by superimposed changes that "influence only externals of life and leave hopes, fears, beliefs, customs and social organization of the masses relatively untouched." These latter factors are most significant, and until they are modified, fertility will continue to remain high. Nevertheless, while considerable efforts have been made to control disease, ${ }^{8}$ little has been done to change popular attitudes towards family limitation.

Fertility depends on ( $\mathrm{r}$ ) the age at which women marry; (2) the period during which they remain in fertile union; and (3) the rapidity with which they build their families. A study based on published census data shows that the mean age of women at marriage has increased from 12.6 in the $192 \mathrm{I}-3 \mathrm{I}$ decade to 15.5 in the $194 \mathrm{I}-5 \mathrm{I}$ decade, while that of men has remained more or less stationary at twenty. ${ }^{\circ}$ The increase of roughly three years in the age of women at marriage within a period of twenty years would, on a rough calculation, result in a three per cent decline in the birth rate. ${ }^{10}$

Another study based on the proportion of widows to married women by age, obtained from the census data, has calculated that while the mean age at widowhood of those widowed until the age of forty-five was 32.8 years in the $192 \mathrm{I}-3 \mathrm{I}$ decade, it increased to 34.4 years in the $194 \mathrm{I}-\mathrm{F}^{\mathrm{I}}$ decade. ${ }^{11}$ This has resulted in a decline in the proportion of widows in the reproductive ages. This decline in the incidence of widowhood during the period $1926-46$ (both taken as the mid-years of the respective decades) would result, roughly calculated, in an increase in the birth rate by about

'Id. at 9-1o.

${ }^{8}$ E.g., while nearly $75,000,000$ people were infected by malaria around 1947 , the number now has gone down to about 5,000,000. It is hoped that by the end of the five-year plan, malaria will be completely eradicated from India. See The Statesman (New Delhi), March 17, 1960, p. 9.

${ }^{9}$ S. N. Agarwala, The Mean Age at Marriage as Ascertained from Census Data, I957 (unpublished thesis in Princeton University Library); Agarwala, The Age at Marriage in India, 23 Population Index 96 (1957).

${ }_{10}$ This has been calculated by applying the age-specific fertility data of Uttar Pradesh collected by the National Sample Survey in the fourth round to the female life-table population of 1951, ANSLEX J. ConLE 8* Edgar M. Hoover, Population Growth and Economic Development in Low-Income Countries 350 (1958); adjusted for marriage by multiplying the life-table population ( $\mathrm{n}^{\mathrm{X}} \times$ values) by the proportions married by age calculated by the present writer from the census data. Incidentally, Coale and Hoover have calculated from this data that the reduction in birth rate would be $4 \%$. Id. at 49.

${ }^{11}$ Agarwala, Mean Duration of Fertile Union in India from Census Data, in Report of the Proceedings of the Sixth International. Peanned Parenthood Conference 89 (1960). 
ten per cent. ${ }^{12}$ There are no figures to show the rate at which widows are remarrying because of the loosening of the social ban on widow remarriages among the upper castes; but the impression is that it is not so great as would result in any substantial increase in the birth rate over the ten per cent calculated above.

A decline in the birth rate could have been brought about through the use of contraceptives by the people. The family-planning movement in India is not yet very powerful, however, and since only an insignificant number of people are known to be using contraceptives, the decline in birth rate attributable to their use is minor. It is, therefore, not surprising that the birth rate in India has not registered any significant decline.

\section{II}

\section{Familly-Planning Movencent in India}

The Government of India is very anxious to propagate family planning among the masses of India. The days when Professor Raghunath Dhondo Karve had to resign his job because he opened a birth-control clinic in Bombay (I925) are gone. Since the r930's, educated opinion in the country has favored family planning. In 1930, the Mysore Government opened a family-planning clinic in the state. Two years later, in I932, the Government of Madras agreed to open birth-control clinics in the Presidency. In the same year, the All India Women's Conference at Lucknow passed a resolution recommending that "men and women should be instructed in methods of birth control in recognised clinics." The National Planning Committee, appointed by the Indian National Congress in 1935 under the chairmanship of Jawaharlal Nehru, strongly supported family planning. ${ }^{13}$ In I936, Dr. A. P. Pillai conducted a family-planning training course. In 1939, some birth-control clinics were opened in Uttar Pradesh and in Madhya Pradesh. In I940, Sri P. N. Sapru successfully moved a resolution in the Council of States (the upper house of the Indian Parliament) for the establishment of birth-control clinics. The Health Survey and Development Committee appointed by the Government of India in 1943 under the chairmanship of Sir Joseph Bhore recommended that provision should be made to open birth-control clinics in various government hospitals. ${ }^{14}$ In 1949, the Family Planning Association of India was formed in Bombay under the presidency of Shrimati Dhanvanthi Rama Rau.

Since the independence, the Government of India has been actively supporting this movement. In the first five-year plan, a provision of $6,500,000$ rupees was made

19 Ibid. This has been calculated in the manner discussed in note Io supra.

${ }^{13}$ See K. T. Shah (ED.), Population (1937). One of the recommendations is that "in the interest of social economy, family happiness and national planning, family planning and a limitation of children are essential and the state should adopt a policy to encourage these." Id. at I74.

${ }^{14}$ The Committee observed: "All of us are agreed that when child-bearing is likely to result in injury to the mother or infant, there is every justification for the practice of contraception. In such cases, it should be the responsibility of the Government to provide instructions regarding contraception in Maternity and Child Welfare Centres, dispensaries, hospitals and any other public institutions which administer medical aid to women." 2 Health Survey and Development Comm., Report 487 (I946). 
for a family-planning program designed to discover effective techniques of family limitation, and to suggest methods by which knowledge of the technique could be widely disseminated. For the second five-year plan, the financial provision was increased to 49,700,000 rupees, and there are indications that it will be raised to $500,000,000$ rupees for the third five-year plan. ${ }^{15}$ The target in the second five-year plan was to open 500 urban and 2,000 rural clinics, so that a family-planning clinic would be available for every 50,000 people in the urban areas and for every 66,000 people in the rural areas.

Considerable progress has been made in the opening of family-planning clinics, both in the urban and in the rural areas. At the beginning of the second five-year plan in 1956, there were only 147 such clinics, twenty-one in the rural areas and 126 in the urban areas. By the end of November 1959, the number of clinics had increased to 1,147 , of which $7^{12}$ were in rural areas. In addition, there wcre 1,318 maternity and child-welfare centers, twenty-one medical colleges, and sixty-three other training centers where family-planning advice was being given. ${ }^{10}$ The $\mathrm{Di}$ rectorate General of Health Services is of the opinion that the family-planning workers have so far contacted roughly 4,700,000 people in the country, and of these, roughly $\mathrm{I}, 000,000$ have taken advice on birth control. Sale of contraceptives is reported to have increased seven-fold during 1958, as compared to 1957 . The Medical Council of India and the Indian Nursing Council have both recommended that family planning should be introduced as a subject of study in their training programs. It has been estimated that during the Family Planning Exhibition held in New Delhi in February 1959, at the time of the Sixth International Planned Parenthood Conference, nearly 80,000 people visited the exhibition and over 12,000 wanted individual advice and were referred to the clinics. ${ }^{17}$ In 1957 , about 12,600 men and women were operated for vasectomy and salpingectomy in India. ${ }^{18}$ The number increased to 22,500 in $x 958$. Figures are not available for the year 1959 , but by the end of July 1959 , nearly 18,000 operations had been performed. ${ }^{19}$ All these go to show that family-planning movement in India is beginning to reach the people.

\section{III}

\section{Attitude of Indian People Regarding Family Planning}

While all this is very well, it is very pertinent to inquire as to the attitude of the people of India, particularly the rural folk, towards family planning. Is it not a fact

15 Director General of Health Services, Familx Planning in India 5, 10 (1959).

${ }^{10}$ Jaswant Singh, Family Planning Programme: Plan and Progress, 3 Swastrus Hind 233 (1959).

${ }^{17}$ Raina, Family Planning and Demographic Research, in Institure of Economic GrowtH, DuLH University, India's Population Growth and Economic Development 3 (1959).

${ }^{18}$ Raina, Sterilization in Family Planning Programme, 3 Swastha Hind 235 (1959).

${ }^{10}$ From figures given in Family Planning News, Jan. 1960, p. 14. According to the statement of the representative of Bombay State made in the Seminar on Family Planning Education held in New Delhi in March 1960, there were 13,000 operations-4,000 vasectomy and 9,000 of salpingectomy-in Bombay State in 1959 . 
that Indian rural masses are God-fearing, illiterate, poor, and orthodox? How, then, are they going to take family planning?

Roughly two dozen family-planning attitude surveys have so far been completed in India. ${ }^{20}$ Seven surveys have been conducted around Calcutta, five around Delhi, four around Poona, three around Bangalore, two near Kanpur, two near Madras, and one each in Lucknow, Ludhiana, and Hyderabad. ${ }^{21}$ These surveys differed considerably as to the questionnaires used and the manner in which the inquiries were conducted. It is not possible to generalize on the basis of the results of these studies, and clearly there is need for more such surveys. If, however, one were to draw on these studies for purposes of policy-making, one would be impressed by the considerable degree of uniformity in the responses on such important matters as the number of children desired, the desirable interval between one childbirth and an-

${ }^{20}$ Following is the list of the family-planning attitude surveys that have been completed in India:

(I) S. N. Agarwala, Beliefs and Practices Relating to Family Planning-A Study of Three DelHI Vilinges (1959); see also Bisht et al., Women's Attitude Towards Family Planning, 3 Swastha Hind 245 (1959); (2) Baljit Singh, Multi-purpose Family Research Project (Five Years of Family Planning in the Countryside) (1958); (3) C. Chandrasekhar, The Mysore Study: Population Trends and Social Economic Development in Selected Areas of Mysore State, India chs. i i-i2 (1958); (4) C. Chandrasekaran, Muktha Sen \& K. K. Mathew, An Enquiry into the Reproductive Pattern of Bengalee Women, 1947-48 (unpublished survey by the Indian Institute of Hygiene and Public Health); (5) S. Chandrasekhar, Family Planning in an Indian Village: Motivations and Methods, 3 Por. Rev. 63 (1959); (6) S. Chandrasekhar, Report on a Survey of Attitude of Married Couples Towards Family Planning in the Putupakkan Area of the City (1959); (7) S. Chandrasekhar, Attitudes of Baroda Mothers Towards Family Planning, in Third INTERnational Conference on Planned Parenthood, Report on the Proceedings 7I (1952); (8) V. M. Dandekar \& Kumudini Dandekar, Survey of Fertility and Moraltty in Poona District II5-87 (Gokhale Institute of Politics and Economics Pub. No. 27, I953); (9) Kumudini Dandekar, Demographic Survey of Six Rural Comaunitres 85-I0I (I959); (I0) Guha, Research on Contraceptives Used by Abhor Hill Tribes, in Director General of Health Services, Family Planning in India app. K., at II3 (1959); (Ir) India-Harvard-Ludhiana Population Study at Khanna, Punjab, id. at I12; (12) Kishore \& Arora, Attitude Towards Family Planning in Najafgarh Health Unit Area, Dellii, Najafgarh News, Sept. 1952, p. I; (13) D. N. Majumdar, Report on the Enquiry Into Fertility and Family Planning Among a Section of Married Women in Kanpur (1955-56); (14) K. K. Mathen, A Survey on the Attitude of Men and Women of Calcutta on Certain Aspects of the Population Problems, All India Institute of Hygiene and Public Health Alumni Ass'n Bull., Jan. I954; (15) A. Mathen, Factors Contributing to Patient Attendance in the Clinic, in Third Alz-India Conference on Family Planning, Report of THe Proceedings 62 (r957); (I6) Indian Institute of Public Opinion, Measurement of Knowledge of Family Planning Amongst Indian Women: A Study in the City of Calcutta, Monthly Public Opinion Surveys, Dec. I958, p. r; (I7) Morrison, Attitude of Females Toward Family Planning in a Western Indian Village, 35 MILbank Memorual Fund Q. 67 (I957); (18) Morrison, Attitudes of Males Toward Family Planning in a Maharaslitrian Village, 34 Milbank Memoriax Fund Q. 262 (I956); (I9) Pannu, A Note on the Attitude of People on Family Planning, in Family Planning Project, NAjafgarh (1959); (20) Pothi, Malakar \& Chakravarti, An Enquiry into the Prevalence of Contraceptives in Calcutta City (1956-57), a paper presented at the Sixth International Planned Parenthood Conference, New Delhi, India, Feb. I959; (2I) Rural Field Study of Population Control, Singur, Calcutta, in DirectoR General of Health Services, Family Planning in India app. K, at 117 (1959); (22) N. V. Sovani \& Kumudini Dandekar, Fertility Survey of Nasik, Kolaba and Satara (North) Districts 50-65 (Gokhale Institute of Politics and Economics Pub. No. 3I, I955); (23) Vasantini, Acceptance of Family Planning in the Rural Study Conducted at Ramanagaram Family Planning Centre, in Third All India Conference on Family Planning, Report of the Proceedings 120 (I957); (24) WHO, Final Report on Pilot Studies in Family Planning (r954); see also Pilot Studies on Rhytlim Method at Lodi Colony and Ramanagaram, in Director General of Health Services, Family Planning in India app. D, at III (I959).

${ }^{21}$ This shows that there have been no family-planning attitude surveys in the states of Assam, Bihar, Orrissa, Madhya Pradesh, Rajasthan, and Kashmir. 
other, the present knowledge about family planning, and the desire to learn methods to control pregnancies. This is very surprising in light of the diverse social and religious practices and living habits of the people of India. For those interested in the success of the family-planning program, however, this is very encouraging.

The family-planning attitude surveys show that while people in the rural areas consider that the ideal family is constituted of four children, ${ }^{22}$ in the urban areas, three children are considered a preferable family size. ${ }^{23}$ In both the rural and the urban areas, however, an interval of three to four years is considered desirable between one childbirth and another. ${ }^{24}$ Knowledge of family planning as well as willingness to learn are significantly correlated with education and the number of living children, but not with caste or religion, ${ }^{25}$ as there is no organized religious or social opposition to family planning. Among the currently married women of the reproductive age group, knowledge of contraceptives varies between ten to twenty per cent in the rural areas and between twenty to thirty per cent in the urban areas. ${ }^{28}$ Willingness to learn family-planning methods was high among those women who had four or more living children and who were thirty-five years of age and older; in fact, roughly seventy per cent of such women were found willing to learn about family planning. ${ }^{27}$

${ }^{32}$ See, e.g., the Lucknow survey conducted by Baljit Singh, the Calcutta surveys conducted by $\mathrm{C}$. Chandrasekaran and others and by K. K. Mathen, the Delhi surveys conducted by S. N. Agarwala and by the Indian Council of Medical Research in Najafgarh, the Mysore survey conducted by $\mathbf{C}$. Chandrasekaran, and the Nasik and Colaba survey conducted by N. V. Sovani and K. Dandekar, supra note 20.

${ }^{23}$ See, e.g., the Kanpur survey conducted by D. N. Majumdar, the Mysore survey conducted by $\mathrm{C}$. Chandrasekaran, and the Calcutta survey conducted by the Indian' Institute of Public Opinion, supra note 20.

${ }^{24}$ See, e.g., the Kanpur survey conducted by D. N. Majumdar, the Najafgarh surveys conducted by the Indian Council of Medical Research, and the Delhi survey conducted by S. N. Agarwala, supra note 20.

${ }^{25}$ See, e.g., the surveys in a Maharastrian village and in a western Indian village conducted by William A. Morrison, the Mysore survey conducted by C. Chandrasekaran, and the Delhi survey conducted by S. N. Agarwala, supra note 20.

${ }^{20}$ E.g., in the Mysore survey conducted by C. Chandrasekaran, $10 \%$ of the women and $15 \%$ of the men had knowledge of family planning. In the Delhi survey conducted by S. N. Agarwala, $19 \%$ of the currently married women had knowledge of contraceptives, while $50 \%$ of them were aware of family planning. In Calcutta, the Indian Institute of Public Opinion found that $83 \%$ of the city folk and $44 \%$ of village folk had knowledge of family planning. In another survey in Calcutta among Bengalee women, C. Chandrasekaran and others found that $20 \%$ of the lower-middle-class women and $50 \%$ of the upper-middle-class women had some knowledge of family planning. In the Kanpur survey conducted by D. N. Majumdar, $7 \%$ of the rural women were found to have knowledge of family planning. See stipra note 20.

${ }^{27}$ In the Baroda survey, S. Chandrasekhar found that $63 \%$ of the Gujrati and $77 \%$ of the Marathi currently married women of reproductive age were willing to learn about family planning. In the Delhi survey, S. N. Agarwala found that $55 \%$ of the currently married women were willing to accept family-planning advice. In Ramanagaram village in Mysore, in $78 \%$ of the couples interviewed, one or both partners expressed a desire to avoid or postpone pregnancy and to learn a method of doing so, and in Lody Colony (New Delhi), 72\% of the women interviewed expressed a desire to learn about family planning. The family-planning pilot research project conducted in some villages in the districts of Lucknow, Meerut, Etawah, and Almorah in Uttar Pradesh showed that $62 \%$ of the mothers and $57 \%$ of the fathers in these rural areas approved of birth control and were eager to learn about family planning. In the Poona survey conducted by the Dandekars, roughly $65 \%$ of the men and $53 \%$ of the women expressed a desire to have information on family planning. See supra note 20. 
The surveys show that in the absence of clinic service, family planning in Indian villages is misunderstood and is taken to mean complete stoppage of childbirths. ${ }^{28}$ Women do have an idea of spacing, but they think that this can be achieved through some rituals performed at the time of the childbirth, and they have little idea that modern contraceptives are also used for this purpose. In the village of Begumpur, near Delhi, a number of interesting beliefs relating to spacing of children have been learned in the course of a survey that is being conducted by the Demographic Research Centre, Delhi. Some women think that if, at the time of the childbirth, a woman counts, say, three beams or girders in the ceiling of the delivery room, her next child will be born only after three years; but if she counts only one or two, her next child will be born after an interval of one or two years. Some believe that if only the floor of the room where the child was born is plastered after the childbirth, another child will be born to the woman after an interval of one year; but if, in addition to the floor, the walls are also plastered, the interval will be two to three years. Some others say that if the cot of the mother is pushed towards the head every day after the childbirth, the interval until the next child will tend to increase; if the cot is pushed only once, the interval will be only one year, but if it is pushed two or three times, the interval will be two or three years. It is unknown to the writer whether information relating to such beliefs is available at other places in India, but if studies are conducted to obtain information relating to such beliefs, it could be utilized to build up a comprehensive educational program.

It is easy to laugh at the simplicity and naiveté of the village folk. But the important fact that emerges is that they are not completely unaware that it is possible to increase the spacing between childbirths and that the village women do make efforts to increase this interval, although their efforts are unavailing. Thus, it can confidently be assumed that if the village women are taught the correct ways to lengthen the interval, they are likely to utilize them.

In the course of the surveys that were conducted in Delhi, it was found that the notorious mother-in-law is not the stumbling block in the path of her daughters'in-law efforts to learn methods of family planning. ${ }^{29}$ Some surveys have shown that

Commenting upon the possibility of the acceptance of family-planning advice, the Dandekars observe that "the most significant fact about the situation, therefore, is the large number of persons, males and females, in the city as well as the non-city area, who said they would welcome information on the subject of family limitation and the substantial number among them who voluntarily said that they would immediately adopt the method in practice." V. M. Danderar \& Kumudini Danderar, Survey of Fertility and Mortality in Poona District I72-73 (Gokhale Institute of Politics and Econiomics Pub. No. 27, 1953). Professor D. R. Gadgil, writing the foreword to this book, says that "while on the one hand, it shows that the actual practice of family planning, even in a city like Poona, is extremely limited in scope, it also reveals a generally receptive attitude, extensive readiness to obtain useful and effective information, and considerable preparedness to adopt family plannning in case the means are suitable and appropriate .... It yet appears clear that there exists no important element in the ideological make-up of the people which would make progress impossible if a movement towards family planning is launched appropriately." Id. at iv.

${ }^{2 B}$ See, e.g., S. N. Agarwala, Beliegs and Practices Relating to Family Planning-A Study of Three Delh! Villages 12 (1959).

${ }^{20}$ Id. at 41 . 
often old women in the villages teach family-planning practices to younger women. The village dai (untrained midwife) also plays an important role in imparting information on the subject to the village women. ${ }^{30}$ The institution of the village dai has not yet been properly utilized, ${ }^{31}$ and her assistance may prove extremely helpful in spreading the knowledge of family planning among the village women.

The men appear to be less interested than the women in family planning. ${ }^{22}$ This is presumably ascribable to the fact that men regard the bearing and rearing of children as the concern solely of women. Since the men make all important decisions concerning the family, however, the women are not in a position to undertake contraception unilaterally. ${ }^{33}$ Very little investigation has been directed toward discovering male attitudes concerning family planning, but it would seem to be a promising area for future surveys.

It appears that the village women are very reluctant to go to a clinic exclusively devoted to family planning. If they visit such a clinic, they become conspicuous and their action is discussed by the village folk. They prefer, instead, to go to a clinic where, in addition to family planning, some other service is also provided, like a general health service or child-welfare activity. If they visit such a clinic, they can always disguise their true purpose and can receive family-planning advice without exciting much publicity and talk in the village. ${ }^{34}$ As a practical step, therefore, a family-planning program is more likely to succeed in India if it is incorporated into the general health program.

\section{IV}

\section{Attutude Surveys and Some Lessons from Thens}

Generalizing on the basis of the results obtained in various family-planning attitudes surveys, it can be said, as has been observed above, that married women above the age of thirty-five and having four or more living children will, in all probability, be receptive to family planning. Efforts should, therefore, be made to educate them in the rudiments of family planning; and at the same time, inexpensive and simple methods of contraception should be made available to them. When these women begin to use contraceptives, there is bound to be a good demonstration effect, and it is likely that women of younger age groups will also be persuaded to adopt these measures.

The attitude of the men, however, is not yet sufficiently known. Nevertheless, since the surveys show that women in the rural areas seldom discuss such subjects

${ }^{20} \mathrm{Id}$. at $25,4 \mathrm{I}$.

${ }^{31}$ This is not because there is any opposition to using the services of the village dai. The fact that the village dai could be helpful in disseminating family planning information has come to light only recently.

82 The Mysore and the Najafgarh surveys show that a larger percentage of men was interested in family planning than females. Other surveys, however, show the opposite results. See supra note 20.

${ }^{3}$ S. N. Agarwala, Beliefs and Practices Relating to Family Planning-A Study op Threb Dechi Villages 13, 4I (1959).

${ }^{34} I d$. at 12,25 . 
as the desirable number of children, the use of contraception, etc., with their husbands, it is quite possible that the husbands do not know the true feelings of their wives. Accordingly, if, as a result of an educational program, women are persuaded to communicate more freely with their husbands concerning these matters, the husbands may conceivably also agree to family-planning practices. This, however, is only a guess.

But despite these helpful signs, much success cannot be achieved unless inexpensive and simple methods of contraception are made available to the rural masses. The Delhi surveys have shown ${ }^{35}$ that village women do not want to spend more than 0.25 to 0.32 rupees-or five to six cents-per month on contraceptives, and they prefer that contraceptives be made available to them without cost. The method also has to be simple. The failure of the rhythm method or the safe-period method in India can be attributed to its complexity. ${ }^{36}$

In Delhi, a tube of contraceptive jelly costs four rupees-or eighty cents; a diaphragm, 4.50 rupees-or ninety cents; a foam tablet, 0.15 rupees-or three cents; and a condom, 0.43 rupees-or eight to nine cents. This means that a person using these contraceptives will have to spend between three to four rupees per month; and Indian village folk are not in a position to spend this much money for this purpose. The Government of India is conscious of the fact that imported contraceptive jellies, creams, and diaphragms are fairly expensive ${ }^{37}$ and that their consumption, therefore, is small. The Government is, accordingly, encouraging research to produce foam tablets within the country, and it is hoped that it may be possible to manufacture them at a unit cost of one naya paisa-or 0.2 cents. The problem of an inexpensive contraceptive will then be solved to a considerable degree.

The Government of India is very desirous of encouraging the domestic production of other contraceptives as well. At present, there are only two manufacturing units with an installed annual capacity of $\mathrm{x}, 600,000$ condoms, but they produce only $159,000 .^{38}$ The current demand for condoms is considered to be 8,000,000 units per year, however, and it is estimated that by I96r, this will increase to about I0,000,000. The Government is willing to provide the necessary facilities for the expansion of existing units and also wishes to encourage new entrepreneurs to undertake the

${ }^{35}$ Id. at 8.

${ }^{30}$ S. Chandraserhar, Population and Planned Parenthood in India $84-86$ (1955).

${ }^{37}$ The following table shows the quantity of condoms imported in India and their value:

$\begin{array}{lcc} & \text { Quantity (dozens) } & \text { Values (rupees) } \\ 1957 & 584,000 & 676,000 \\ 1958 & 362,000 & 409,000 \\ 1959 & 302,000 & 331,000\end{array}$

Seetharamiah \& Rao, Manufacture of Contraceptives in India, Family Planning News, Feb. I960, p. I4.

${ }^{38}$ The following table shows the production of condoms in India:

$\begin{array}{lr}1955 & 111,552 \\ 1956 & 78,612 \\ 1957 & 108,456 \\ 1958 & 115,760 \\ 1959 & \times 58,736\end{array}$

Ibid. 
manufacture of condoms in collaboration with some well-known foreign firms. It is hoped that the market prices of the contraceptives will then decline.

Many in India pin their hopes on an oral contraceptive, because of its simplicity and convenience. Research is being carried out in Singur on a controlled group of women to find out the efficacy of meta-xylohydroquinone. ${ }^{39}$ Definitive results are not available. Nevertheless, divergent views have been expressed on the desirability of using oral contraceptives, and some have expressed the fear that their regular and continued use may cause seriously harmful side-effects. This is a matter for further research and experimentation. The need for a safe contraceptive, however, is as great as that for an inexpensive one. If by any chance a contraceptive proves harmful, this is likely to create such a bad effect that for many years to come, village folk will not think of using any of them. Therefore, utmost caution must be exercised to prescribe only contraceptives of proven safety and reliability.

\section{V}

\section{The Efrectineness of Contraceptives}

It is obvious that the availability of simple, safe, inexpensive, and reliable methods of contraception alone will not solve the problem of population control. People have to be motivated and trained to use contraceptives regularly and properly. A contraceptive's effectiveness is known to differ according to some socioeconomic characteristics of its users, such as income, education, employment status, etc., as well as according to the character of the instruction concerning its use, the physiological and psychological characteristics of its users, their marital relationship, and the urgency of their felt need to prevent conception. ${ }^{40}$ Therefore, it is to be expected that different groups of people will attain varying degrees of success in using the same contraceptive.

Under laboratory conditions, all contraceptives are nearly too per cent effective. But in actual practice, either because the users do not follow proper advice carefully, or because of the failure on the part of the clinic staff to give them proper advice, there are accidental pregnancies. Because of these factors, it is hazardous to expect that a contraceptive will prove as effective in one country as in the other.

There is only one study in India that deals with the effectiveness of contraceptives. ${ }^{41}$ It covers participants in the contributory-health-service scheme clinics of Delhi, drawn from the moderate-income group of the working middle classes. The mean family income of the patients studied in the report was 214 rupees-or fortyfive dollars--per month. Roughly twenty-nine per cent of the patients reported monthly incomes between ror and I50 rupees-or twenty to thirty dollars; nineteen

${ }^{30}$ Basu, Family Planning Studies at Singur, 3 Swastha Hind 247 (1959).

${ }^{\circ 0}$ R. K. Stix \& F. W. Notestein, Controlled Fertility 4 (1940).

${ }^{4}$ S. N. Agarwala, Fertility Control Through Contraception: A Study of Family Plannino Clinics of Metropolitax Delm (1959). A brief version of the report has appeared in Family Planning News, Feb. 1960, p. I, and also in Your Health, Feb. 196o, p. 57. 
per cent, between $15 \mathrm{I}$ and 200 rupees-or thirty to forty dollars; and twenty-three per cent, between 201 and 300 rupees-or forty to sixty dollars. The patients were mostly literate-eighty-nine per cent of the women and ninety-nine per cent of the men could read and write. Nearly eighty-eight per cent of the literate women had attended a school, and ninety-two per cent of the literate men had received up to ten. years of formal schooling or more. Ninety-eight per cent of the women were housewives, and most of their husbands were government servants-clerks or officers.

The average age of the women at the time of their first enrolment in these clinics. was found to be twenty-seven years, and that of their husbands thirty-two years. Nearly seventy per cent of the women were enrolled when they were below the ageof thirty years, and nearly eighty per cent of the men while they were between thirtyfive and thirty-nine years of age. At the time of first enrolment in these clinics, the couples had been married, on an average, roughly ten years each; had experienced, on an average, 4.x pregnancies, out of which 3.6 resulted in live births; and had, on an. average, 3.2 living children.

Of the 5,912 patients studied, only 3,424, or fifty-eight per cent, had practiced one or more methods of contraception before clinic attendance, and the remaining fortytwo per cent had not. Among the methods reported as having been used, the condom was most common, which attests its strong appeal to the "untutored con-. traceptors."

The patients who had never used any contraception before clinic attendance had. a pregnancy rate of sixty-six per roo years of exposure, ${ }^{42}$ while the patients who had. had some contraceptive experience prior to clinic attendance had a pregnancy rate of sixty-two per roo years of exposure for the period when no contraceptive had been used. There is little difference between the two pregnancy rates, and this suggests. that the contraceptors and the noncontraceptors were similar in their fertility performance. The pregnancy rate for the contraceptors for the period when somemethod of contraception had been used prior to clinic attendance, however, was. thirty-five per 100 years of exposure, which shows that even without clinic service, these patients had reduced their risk of pregnancy by nearly forty-three per cent..

For a majority of the patients who came to the clinics for advice, the diaphragm: and jelly were prescribed. The second most commonly prescribed contraceptive method was the condom and jelly. The pregnancy rate per roo years of exposure for the diaphragm and jelly was ten; for the condom and jelly, fifteen. These results. compare very favorably with those obtained in some western countries, as table four shows.

\footnotetext{
"For the method of computing pregnancy rates, see Tietze, The Clinical Effectiveness of Contraceptive Methods, 78 Asr. J. OBsteT. \& Grnecos. 650 (1959). Cf. Tietze, The Current Status of; Fertility Control, supra pp. 426, 437 .
} 
TABLE IV

Pregnancy Rates for Diaphragm and Jelly

\begin{tabular}{|c|c|c|c|c|c|}
\hline Investigators & Year & Place & $\begin{array}{l}\text { Years of } \\
\text { Exposure }\end{array}$ & $\begin{array}{l}\text { Number of } \\
\text { Pregnancies }\end{array}$ & $\begin{array}{l}\text { Pregnanoy } \\
\text { Rate }\end{array}$ \\
\hline 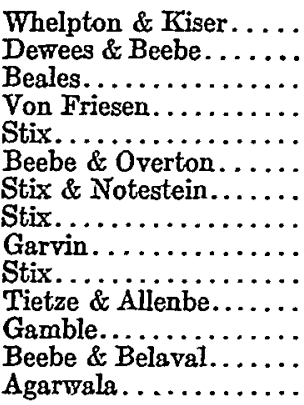 & $\begin{array}{l}1942 \\
1938 \\
1938 \\
1957 \\
1939 \\
1942 \\
1940 \\
1941 \\
1944 \\
1941 \\
1959 \\
1955 \\
1942 \\
1959\end{array}$ & $\begin{array}{l}\text { Indianapolis } \\
\text { Philadelphia } \\
\text { New York } \\
\text { Sweden } \\
\text { Cincinnati } \\
\text { Nashville } \\
\text { New York City } \\
\text { South Carolina } \\
\text { Spartanburg } \\
\text { Spartanburg } \\
\text { Barbados } \\
\text { India \& Pakistan } \\
\text { Puerto Rico } \\
\text { Delhi }\end{array}$ & $\begin{array}{r}865 \\
935 \\
\dddot{280} \\
2703 \\
361 \\
703 \\
685 \\
\ldots \\
\ddot{503} \\
151 \\
150 \\
1004\end{array}$ & $\begin{array}{r}38 \\
59 \\
\ddot{23} \\
244 \\
32 \\
65 \\
87 \\
\cdots \\
\ddot{87} \\
32 \\
43 \\
92\end{array}$ & $\begin{array}{r}4 \\
6 \\
7 \\
8 \\
9 \\
9 \\
0 \\
13 \\
11 \\
13 \\
17 \\
21 \\
29 \\
10\end{array}$ \\
\hline
\end{tabular}

Sources: Westoff, Herrera \& Whelpton, Social and Psychologioal Factors Affecting Fertility: The Use, Effctirencss and Acceplabilily of

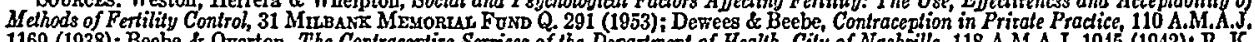
1169 (1938); Beebe \& Overton, The Contraceptize Serrices of the Department of Heall, Cuty of Nash iille, 118 A.M.A.J. 1015 (1942); R. IT.

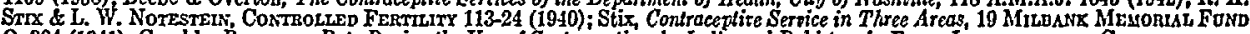

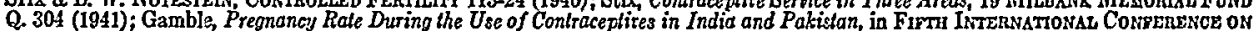

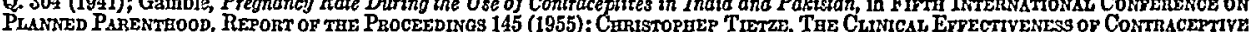

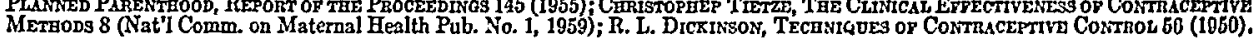

It was discovered in this study that the pregnancy rates of the patients varied inversely with such socioeconomic factors as income, education, employment status, etc. Thus, the pregnancy rate of the patients educated up to and beyond the secondaryschool level, having a monthly income of more than 200 rupees, and belonging to the "officer" class was lower than that of any other group, as appears clearly in table five.

TABLE V

Pregnancy Rates by Some Socioeconomic Characteristics

\begin{tabular}{|c|c|}
\hline Characteristics & Pregnancy Rate \\
\hline All women $\ldots \ldots \ldots \ldots \ldots \ldots \ldots \ldots \ldots \ldots \ldots \ldots \ldots \ldots \ldots$ & 12.6 \\
\hline $\begin{array}{l}\text { Education of women } \\
\text { High School and above } \ldots \ldots \ldots \ldots \ldots \ldots \ldots \ldots \ldots \ldots \ldots \ldots \ldots \ldots \ldots \\
\text { Below High School. } \ldots \ldots \ldots \ldots \ldots \ldots \ldots\end{array}$ & $\begin{array}{l}10.0 \\
14.4\end{array}$ \\
\hline $\begin{array}{l}\text { Family income(monthly) } \\
\text { Rs. } 201 \text { and above. } \\
\text { Up to Rs. } 200 \ldots \ldots \ldots \ldots \ldots \ldots \ldots \ldots \ldots \ldots \ldots \ldots \ldots \ldots \ldots \ldots \ldots \ldots \ldots \\
\end{array}$ & $\begin{array}{l}10.9 \\
14.1\end{array}$ \\
\hline 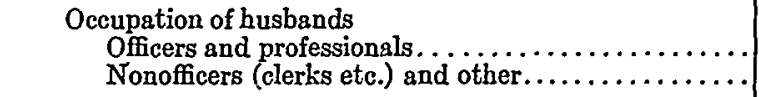 & $\begin{array}{r}9.7 \\
13.6\end{array}$ \\
\hline
\end{tabular}

This study showed that the patients reduced their risk of pregnancies by eightyfour per cent through the use of clinically-prescribed contraceptives. Even illiterate patients and those who had not reached the secondary-school level of education, whose monthly income was 200 rupees and less, and who were employed as clerks and peons in the Government, had a pregnancy rate of fourteen, as compared with a pregnancy 
rate of ten for those with a better education, better employment, and better income. This suggests that even the lowly-placed patients achieved considerable success through contraception. This is very encouraging, since it shows that if ways can be found to motivate people to undertake contraception, it may be possible to bring about a reduction in the risk of pregnancy by about sixty per cent. ${ }^{\mathbf{4 3}}$ This is a figure midway between eighty-four and thirty-two per cent, the reductions in the risk of pregnancies experienced by the patients through contraception, with and without clinic service.

VI

\section{Cost of a Family-Planning Program}

It is proposed here roughly to calculate the cost of a program aimed at distributing contraceptives gratuitously to either of the married partners with three or more children, where the wife is within the reproductive age-group. First, it is necessary to ascertain the number of couples who need be approached for contraceptive distribution, and then this figure must be multiplied by the cost of the contraceptive. One of the ways of estimating the number of couples is to determine the number of currently married women of the reproductive age group with three or more children. At the time of the 195 I census, nearly 79,000,000 women were of the reproductive age-group-that is, between the ages of fifteen and forty-five years. Of these, roughly ten per cent, or $8,000,000$, were widows. If the national policy is to persuade couples to have only three children, as was suggested by the 195I Census Commissioner, then only the currently married women of the twentyfive-to-forty-five-year age group need be reached, since Indian women have an average of three children by the age of twenty-five. ${ }^{44}$ It may, perhaps, be desirable to approach women a few years before they have borne their third child-say, when they are twenty years of age. This means that a total of about 50,000,000 women would have to be reached, as of 195 I. $^{45}$

As far as the relative effectiveness of the costly versus the less costly and the complicated versus the simple methods of contraception is concerned, there is not much difference, as may be seen in table six. Annual cost has been estimated on the basis of the contraceptive requirements for fifty to sixty copulations per year.

\footnotetext{
${ }^{43}$ It may be pointed out that the Government of India has already appointed 17 family-planning education leaders in different parts of the country, and it is proposing to appoint another 20 leaders. These leaders address meetings, arrange group discussions, and seek to motivate people and mobilize public opinion in favor of family planning. For details of the good work of some of the leaders, see Family Planning Village Leaders, Family Planning News, Feb. 1960, p. I8. The Government is also proposing to open 5 research centers in different parts of India to perfect methods of communicating the idea of family planning among the people. The Ford Foundation has given a grant of $\$ 300,000$ to the Government for this purpose. Ford Foundation Grant, Family Planning News, Jan. r960, p. II.

"This is clear from the data on age-specific fertility rates obtained from the demographic surveys in Poona, Kolhapur, Mysore, and others. See V. M. Dandekar \& Kumudini Dandekar, Survey oz Fertility and Mortality in Poona District (Gokhale Institute of Politics and Economics Pub. No. 27, 1953); N. V. Sovant, The Social Survey of Kolmapur Crty 45 (1948).

'S I Census of INDIA, I95I, pt. II-A, at 215-17.
} 
TABLE VI

Effectiveness and Cost of Some Selected Contraceptives

\begin{tabular}{|c|c|c|}
\hline Method & Effectiveness & $\begin{array}{l}\text { Yearly Cost if Manufac } \\
\text { tured in India }\end{array}$ \\
\hline 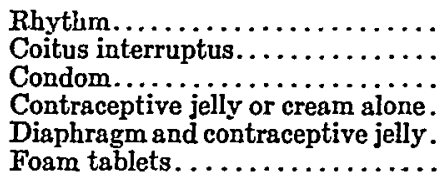 & $\begin{array}{l}\text { Fair } \\
\text { Good } \\
\text { Good } \\
\text { Good } \\
\text { Good } \\
\text { Good }\end{array}$ & $\begin{array}{l}\text { Nil } \\
\text { Nil } \\
\text { Rs. } 3 \text {, or } \$ .60 \\
\text { Rs. } 4-6 \text {, or } \$ .80-\$ 1.20 \\
\text { Rs. } 10-14 \text {, or } \$ 2 .-\$ 2.80 \\
\text { Rs. } 3 \text {, or } \$ .60\end{array}$ \\
\hline
\end{tabular}

If it were possible to manufacture diaphragms and contraceptive jelly in India and if the personnel-time necessary for instructing the patients and in fitting the diaphragms was the same as that found in the Lodi Colony clinic, then the cost of serving the estimated 50,000,000 currently married women of the twenty-to-forty-fiveyear-old age-group would total 500,000,000 rupees per year. For foam tablets, however, the cost would be only 150,000,000 rupees per year. This does not include the cost of distribution, but if the services of the primary health centers and of the village dais are made available gratuitously for contraceptive distribution, perhaps this cost could be avoided. Should the annual number of copulations average roo, instead of the fifty to sixty estimated, the cost of the program would increase to $1,000,000,000$ rupees per year if diaphragms and contraceptive jelly are prescribed, and 300,000,000 rupees per year if foam tablets are prescribed.

This cost is quite formidable, and it is unlikely that the Government will be in a position to spend this much money in this way each year. This may be one of the reasons why some persons have proposed vasectomy as a solution. Such an operation performed on 50,000,000 men, at a cost of twenty rupees per operation, would rentail a total cost of $1,000,000,000$ rupees. The Government could have a phased program spread over a period of ten years for performing the necessary operations on the existing population and also on those who enter the critical age-group. By way of contrast, the cost of gratuitous condom distribution to the 50,000,000 currently married men would amount to $150,000,000$ rupees per year on the basis of fifty to sixty copulations per year, and 300,000,000 rupees on the basis of 100 .

\section{ConcLusion}

All things considered, there is good reason to feel encouraged about prospects for the success of a family-planning program in India. The village folk can be won over to contraception, provided a well-thought-out educational program is launched to overcome their prejudicies. This will involve hard work for a long time, and it would be fatuous to expect that results will be forthcoming quickly. The Government will also have to spend between $150,000,000$ and 500,000,000 rupees per year before a significant decline in the birth rate can be anticipated. 